ROCZNIKI HUMANISTYCZNE

Tom LXIX, zeszyt 2 - 2021

DOI: https://doi.org/10.18290/rh21692-8

GOR ORDYAN

ADAM POMIECIŃSKI

\title{
WIELKI ZRYW MAŁEGO NARODU: ZAPOMNIANY RUCH KARABASKI (1988-1990)
}

\section{WSTĘP}

Okres pierestrojki w Związku Radzieckim spowodował ożywienie ruchów narodowych w Armenii i innych republikach sowieckich. Do jednego z najważniejszych tego czasu należał ruch karabaski, którego głównym celem było włączenie Górskiego Karabachu do Armenii ${ }^{1}$ i oderwanie go od terytorium Azerbejdżanu. Jednak to tylko część żądań jego przedstawicieli. Ruch karabaski był jednocześnie ruchem skierowanym przeciwko polityce władz sowieckich, które przez lata tłumiły antagonizmy ormiańsko-azerskie. Etnolodzy ormiańscy, tacy jak Lewon Abrahamyan² i Harutyun Marutyan, definiują go w kategoriach „ormiańskiej rewolucji”, która była pierwszą wśród rewolucji „bloku wschodniego” końca lat $80 . \mathrm{XX} \mathrm{w.}{ }^{3}$

Mgr Gor ORDYAN - Wydział Kulturoznawstwa Państwowego Uniwersytetu w Erywaniu (Armenia); e-mail: gor.ordyan@gmail.com; ORCID: https://orcid.org/0000-0003-4625-9918.

Dr hab. ADAM POMIECIŃSKI, prof. UAM - Instytut Antropologii i Etnologii Uniwersytetu im. Adama Mickiewicza w Poznaniu; e-mail: adpom@amu.edu.pl; ORCID: https://orcid.org/00000002-1788-1065.

${ }^{1}$ Por. P. OlszewsKI, „Konflikt azerbejdżańsko-ormiański o Górski Karabach”, w Sąsiedztwo i pogranicze - między konfliktem a wspótpraca, t. I, red. R. Łoś, J. Regina-Zacharski (Łódź: Wydawnictwo Uniwersytetu Łódzkiego, 2012), 176.

${ }^{2} \mathrm{~W}$ przypadku oryginalnych nazwisk ormiańskich (działaczy, polityków itp.) stosujemy transkrypcję uproszczoną za: A. PISOwICZ, „O polskiej transkrypcji wyrazów ormiańskich”, Przegląd Orientalistyczny 2 (1979): 158-162. W przypadku pisowni nazwisk ormiańskich naukowców stosujemy angielską transkrypcję w celu ułatwienia identyfikacji źródeł.

${ }^{3}$ L. Abrahamyan, „Chaos and Cosmos in the Structure of Mass Popular Demonstrations (The Karabakh Movement in the Eyes of an Ethnographer)", Anthropology \& Archeology of Eurasia 29, 
Warto jednak zaznaczyć, że na samym początku ruch karabaski nie posługiwał się retoryką antyradziecką. Ormianie wierzyli, iż zmiany są możliwe $\mathrm{w}$ ramach pieriestrojki i postulowanych reform systemu komunistycznego w Związku Radzieckim. Nastroje antykomunistyczne wzbierały na sile z czasem, to znaczy od momentu, kiedy idee niepodległości Armenii i inkorporacji do niej Górskiego Karabachu zaczęły być artykułowane coraz głośniej.

Ruch karabaski, którego aktywność przypada na lata 1988-1990, pozostaje wciąż słabo rozpoznawalny. Naszym zdaniem przyczyn tego stanu rzeczy jest kilka, co więcej, odnoszą się one zarówno do historii, jak i współczesnych procesów politycznych dotyczących relacji rosyjsko-ormiańsko-azerskich na obszarze Kaukazu. Od samego początku ruch karabaski pozostawał „niezauważony", gdyż władze komunistyczne blokowały informacje o masowych wystąpieniach i protestach Ormian. Konflikt azersko-ormiański wraz z kwestią Górskiego Karabachu był skutecznie tłumiony i wyciszany. Prócz tego pod koniec lat 80 . XX w. światowa uwaga skupiona była nie na wydarzeniach dziejących się na „odległym” Kaukazie, lecz koncentrowała się na Europie Wschodniej, np. na masowym ruchu Solidarności w Polsce, upadku muru berlińskiego i zjednoczeniu Niemiec. Dopiero wojna w Górskim Karabachu, która rozgorzała po uzyskaniu niepodległości przez Armenię i Azerbejdżan, przykuła zainteresowanie problemami tego regionu świata. Jednak to sama wojna, a nie ruch karabaski, zwróciła ku sobie ciekawość światowej opinii publicznej.

Obecnie nie bez znaczenia pozostają relacje polityczne na Kaukazie, które nie sprzyjają lepszemu poznaniu ruchu karabaskiego. Od lat 90. XX w. kolejne rządy Armenii starają się zachowywać dystans wobec niego. Ruch karabaski ze swoją antyradziecką retoryką pozostaje bowiem wciąż „niewygodny" dla relacji politycznych Armenii z Rosją, która przypisuje coraz większą rolę mocarstwowemu dziedzictwu byłego ZSRR. Dowodem na to jest fakt, iż władze armeńskie odmówiły w 2018 r. świętowania przez naród ormiański 30. rocznicy powstania ruchu ${ }^{4}$. Obchody trzydziestolecia prezentowały się nadzwyczaj skromnie. Również władze Azerbejdżanu usiłują na różne sposoby „grać kartą” ruchu karabaskiego, aby w ten sposób oddziaływać na stosunki armeńsko-rosyjskie ${ }^{5}$.

nr 2 (1990): 70-86; H. MARUTYAN, „Iconography of Historical Memory and Armenian National Identity at the End of the 1980s", w Representations on the Margins of Europe. Politics and Identities in the Baltic and South Caucasian States, ed. T. Darieva, W. Kaschuba (Frankfurt-Chicago: Chicago University Press, 2007), 89-113.

${ }^{4}$ Więcej na ten temat można znaleźć: https://www.aravot.am/2018/02/03/935075/ (dostęp: 15.02.2020)

${ }^{5}$ Zob. https://voiceofkarabakh.com/raspad_sssr.php; https://haqqin.az/news/165162; https:// haqqin.az/news/99039 (dostęp: 15.02.2020). 
Celem tego artykułu jest rekonstrukcja najważniejszych działań ruchu karabaskiego i próba zrozumienia jego wpływu na procesy, które przyczyniły się do upadku Związku Radzieckiego w kontekście przemian Europy Wschodniej. Historia ruchu karabaskiego rozpoczęła się wraz z masowymi demonstracjami Ormian w lutym 1988 r., którzy domagali się przyłączenia Górskiego Karabachu do Armeńskiej SRR, a zakończyła w sierpniu 1990 r., w chwili przyjęcia deklaracji o niepodległości Republiki Armenii. Wkrótce potem rozpoczęła się faza zbrojna konfliktu między Armenią a Azerbejdżanem o Górski Karabach. Niniejszy artykuł nie opisuje już działań wojennych po uzyskaniu suwerenności przez oba kraje. Skupia się wyłącznie na oddolnym ruchu społecznym przez pryzmat jego działań, ideologii i celów. Przyjmuje antropologiczną perspektywę interpretacyjną w badaniach nad ruchami społecznymi, którą zaproponowali Donatella della Porta i Mario Diani, opierającą się na czterech zbiorach pytań. Pierwszy dotyczy strukturalnych zmian i przekształceń wzorów konfliktów społecznych, drugi roli reprezentacji kulturowych w konflikcie społecznym, trzeci odnosi się do wartości, które ulegają przekształceniu w zbiorowe działania, a ostatni wskazuje na konteksty (społeczne, kulturowe, polityczne) warunkujące powodzenie działań, które podejmują aktywiści i zwolennicy ruchu ${ }^{6}$. Wszystkie te cztery komponenty rozpoznać można $\mathrm{w}$ analizowanych akcjach ruchu. $\mathrm{W}$ trakcie pisania niniejszego tekstu wykorzystaliśmy zarówno dostępną literaturę na temat ruchu karabaskiego (przede wszystkim autorów ormiańskich), jak też rozmowy z jego sympatykami i dawnymi członkami, które odbyliśmy w lutym 2018 r. w Erywaniu. Pomoc stanowiły dla nas materiały ze zbiorów archiwalnych (m.in. fotografie, plakaty, ulotki), dostępne w Muzeum Historii Armenii w Erywaniu. Jako obserwatorzy mieliśmy okazję przyglądać się skromnym obchodom 30-lecia ruchu karabaskiego zorganizowanym przez Kongres Narodowy Armenii w pobliżu erywańskiej Opery 20 lutego 2018 r.

\section{ODDOLNE RUCHY SPOŁECZNE W ARMEŃSKIEJ SOCJALISTYCZNEJ REPUBLICE RADZIECKIEJ}

Związek Radziecki, którego Armenia stanowiła najmniejszą republikę, był państwem totalitarnym, w którym ideologie polityczne inne niż komunizm były zdecydowanie zwalczane, a wszelkie oddolne ruchy społeczne uważano

\footnotetext{
${ }^{6}$ D. DElla Porta, M. Diani, Ruchy społeczne. Wprowadzenie, przeł. A. Sadza (Kraków: Wydawnictwo Uniwersytetu Jagiellońskiego, 2009), 6-7.
} 
za niebezpieczne i zagrażające stabilności systemu ${ }^{7}$. Publiczne działania organizowane były wyłącznie przez państwo, nic nie mogło wydarzyć się bez wiedzy partii komunistycznej. Pomimo tego - jak zauważają Ingrid Oswald i Viktor Voronkov - obok oficjalnej sfery publicznej (public sphere) funkcjonowała niezależna sfera prywatna (private sphere). Swobodne wyrażanie opinii na zewnątrz czy otwarta dyskusja polityczna nie były możliwe ${ }^{8}$. Należy także pamiętać, że sama sfera prywatna pozostawała pod czujnym okiem sowieckiej kolektywności. Przynajmniej teoretycznie rozważano zastąpienie opozycji „publiczne - prywatne” komplementarnością między tym, co wspólne, a tym, co osobiste. Wszyscy członkowie społeczeństwa mieli dzielić ideały i wartości socjalistyczne oraz wnosić swój wkład w dobro wspólne9. Również wszelkiego typu kultury alternatywne stawały się częścią nieformalnej strefy społeczeństwa ${ }^{10}$. Były one w opozycji do władzy, oficjalnej kultury i socjalistycznego modelu człowieka.

Jak wskazują Elena Zdravomyslova i Viktor Voronkov, ruchy społeczne, przede wszystkim dysydenckie i na rzecz praw człowieka zaczęły pojawiać się w ZSRR w latach 60. XX w. i składały się głównie ze środowisk liberalnej inteligencji. Pod koniec lat 60 . i na początku lat 70 . władze radzieckie stłumiły sprzeciwy, a wielu dysydentów wyemigrowało lub zostało uwięzionych ${ }^{11}$. Niezależny aktywizm $\mathrm{w}$ Armenii pojawił się w tym samym okresie. Miał on jednak zupełnie inne podłoże.

Pierwsze publiczne wystąpienia w Armeńskiej Socjalistycznej Republice Radzieckiej, które nie były kontrolowane przez władze centralne i partię komunistyczną, miały miejsce w kwietniu 1965 r. W tym okresie kilka tysięcy Ormian zebrało się w Erywaniu, domagając się uznania i upamiętnienia po pięćdziesięciu latach milczenia ludobójstwa Ormian, popełnionego na ich anatolijskich przodkach w Imperium Osmańskim w latach 1915-1917 ${ }^{12}$. To

${ }^{7}$ S. FitzPATRIC, Everyday Stalinism. Ordinary life in extraordinary times: Soviet Russia in the 1930s (New York-Oxford: Oxford University Press, 1999), 7-9.

${ }^{8}$ I. OSWALD, V. VORONKOV, „The 'public-private' sphere in Soviet and post-Soviet society. Perception and dynamic of 'public' and 'private' in contemporary Russia”, European Societies 6, nr 1 (2004): 97-117.

${ }^{9}$ L. ZAKHAROVA, ,Soviet Public Sphere”, Politika, 16.05.2017, https://www.politika.io/en/notice/ soviet-public-spheres (dostęp: 28.02.2020).

${ }^{10}$ L. LYYTIKÄInEN, Performing Political Opposition in Russia. The Case of the Youth Movement Oborona (Helsinki: University of Helsinki, 2014), 24.

${ }^{11}$ E. Zdravomyslova, V. Voronkov, „The Informal Public in Soviet Society: Double Morality at Work", Social Research 69, nr 1 (2002): 55-56.

${ }^{12}$ S. PAPAZYAn, „The Cost of Memorializing. Analyzing Armenian Genocide Memorials and Commemorations in the Republic of Armenia and in the Diaspora", International Journal for History, Culture and Modernity 7 (2019): 61 
spóźnione upamiętnienie miało być spowodowane koniecznością przerwania ciszy na temat straszliwej traumy narodu ormiańskiego. Odwilż polityczna za czasów Chruszczowa, a także nagłośniona historia o holokauście narodu żydowskiego stworzyły dobre warunki do tego, aby publicznie wyartykułować żądania uznania i potępienia również ludobójstwa Ormian.

Tysięczne manifestacje na ulicach Erywania zaskoczyły zarówno władze lokalne, jak i władze w Moskwie. W akcjach tych główną rolę odgrywała młodzież oraz studenci, którzy opuścili budynki uniwersytetów i wyszli na ulice. Protestujący spotkali się na Placu Lenina, a następnie przeszli pod budynek Opery. Po drodze do maszerującej młodzieży i studentów dołączali inni. Protestujący, zebrani w pobliżu erywańskiej Opery, wezwali przedstawicieli Ormiańskiej Partii Komunistycznej do budowy pomnika ludobójstwa, a także domagali się wywarcia presji na władzach Związku Radzieckiego w celu powrotu do macierzy historycznych ziem ormiańskich, które znalazły się po wojnie w Turcji i Republice Azerbejdżanu ${ }^{13}$. W trakcie manifestacji dochodziło do starć z milicją, a niektórzy z protestujących zostali aresztowani.

Protesty te miały duże znaczenie dla Ormian. Przede wszystkim spowodowały, że lokalne władze zwróciły się do Moskwy o budowę pomnika upamiętniającego rzeź Ormian. Rozpoczęta została także dyskusja o problemach narodowych w Związku Radzieckim. Wreszcie nieszczęście ludobójstwa publicznie artykułowane na ulicach Erywania stało się źródłem kształtowania wspólnej świadomości narodowej wśród rozproszonej ludności ormiańskiej, zmniejszając tym samym dystans pomiędzy sowiecką Armenią a diasporą ormiańską na całym świecie ${ }^{14}$. Po krótkotrwałej odwilży politycznej w Związku Radzieckim władze przyjęły bardziej konserwatywny kurs swoich rządów, powodując, że oddolne ruchy i inicjatywy społeczne zostały w zasadzie zablokowane.

Sytuacja zmieniła się dopiero w latach 80., kiedy do władzy doszedł Michaił Gorbaczow i rozpoczął politykę pierestrojki. Zmiany społeczne miały dotyczyć niemal wszystkich sfer działalności państwa sowieckiego: polityka jawności (głasnost), ograniczenie cenzury, demokratyzacja życia publicznego, projekty wprowadzenia mechanizmów rynkowych. Niektórzy politykę taką nazwali „rewolucją z góry” ${ }^{15}$. Często projekty reform i postulaty realnej poprawy sytuacji ludzi w ZSRR pozostawały wyłącznie w sferze dyskusji.

\footnotetext{
${ }^{13}$ IBIDEM, 61-62.

${ }^{14}$ R. SunY, „Writing Genocide: The Fate of the Ottoman Armenians”, w A Question of Genocide. Armenians and Turks at the End of the Ottoman Empire, ed. R.G. Suny, F.M. Gocek, N.M. Naimark (Oxford-Nowy York: Oxford University Press, 2011), 24.

${ }^{15}$ N. Edelman, „Революция сверху’ в России”, НАУКА И ЖИЗНЬ 1-3 (1989), http:// vivovoco.astronet.ru/VV/PAPERS/NYE/REV/REV_1.HTM (dostęp: 28.02.2020).
} 
Niemniej ta nowa polityka dawała szanse na oddolną aktywność społeczną. Bunty podsycała pogarszająca się sytuacja gospodarcza w ZSRR, która wywołała falę strajków robotniczych. W połowie lat 80 . aktywne stawały się także ruchy ekologiczne. W Armenii pierwsze ruchy na rzecz ochrony środowiska były inicjowane w latach 1986-1988. Aktywiści domagali się zamknięcia Zakładów Chemicznych „Nairit” i elektrowni jądrowej w Mecamorze. Zanieczyszczenie powietrza w Erywaniu i innych miastach ormiańskich stanowiło poważne zagrożenie dla mieszkańców. W latach 80 . XX w. coraz bardziej zaczęto dostrzegać zmiany środowiskowe w następstwie uprzemysłowienia i urbanizacji oraz wzrost różnorodnych schorzeń wśród ludności republiki. Ujawniły się one zwłaszcza w Kotlinie Ararackiej wokół Erywania, gdzie nastąpiła największa koncentracja przemysłu i ludności. Między innymi przejawem reakcji społecznej był list otwarty 350 ormiańskich intelektualistów przeciwko zatruwaniu środowiska naturalnego, który skierowali w marcu 1986 r. do radzieckiego przywódcy Michaiła Gorbaczowa. Również kierownictwo Armeńskiej SRR zdecydowało się podjąć te kwestie, czego wyrazem była zapowiedź przez I sekretarza KPA Karena Demircziana ograniczenia zanieczyszczeń w głównych zakładach chemicznych w Erywaniu i Kirowakanie. Opieszałość władz w rozwiązywaniu tego typu problemów oraz ujawnienie rzeczywistych rozmiarów zanieczyszczeń doprowadziło w drugiej połowie 1987 r. do wielotysięcznych demonstracji ruchu ekologicznego w Erywaniu ${ }^{16}$.

W połowie 1988 r. ruchy te dołączyły do swojej retoryki inne postulaty m.in. domagały się szerszych praw dla Ormian, reform politycznych i w końcu niepodległości dla Armenii. Dla Ormian zanieczyszczenie środowiska było traktowane w kategoriach ludobójstwa ekologicznego, podobnie jak dyskryminacja Ormian w Górskim Karabachu utożsamiana była z ludobójstwem kulturowym. Ormianie powiązali te dwie kwestie z ludobójstwem z 1915 r. przeprowadzonym na ich przodkach w Imperium Osmańskim. Jak zauważył Ohannes Geukjian, ormiański ruch ekologiczny dość szybko ewoluował w kierunku ruchu narodowościowego z wyraźnymi aspiracjami politycznymi ${ }^{17}$. Postępujące w tym samym czasie osłabienie systemu represji i załamywanie się

${ }^{16}$ P. NieCZUjA-OSTROwSKI, „Państwo i społeczeństwo wobec wyzwań i przemian współczesności”, w Armenia. Dziedzictwo a współczesne kierunki przemian kulturowo-cywilizacyjnych, red. P. Nieczuja-Ostrowski (Poznań: Fundacja na rzecz Czystej Energii, 2016), 65.

${ }^{17}$ O. Geukjian, „The Politicization of the Environmental Issue in Armenia and NagornoKarabakh's Nationalist Movement in the South Caucasus 1985-1991", Nationalities Papers 35, nr 2 (2007): 233. 
ZSRR jako państwa unitarnego złożonego z republik sprzyjało ożywieniu idei narodowościowych. Właśnie na tej fali powstał ruch karabaski.

\section{PROBLEM GÓRSKIEGO KARABACHU I KSZTAŁTOWANIE SIĘ RUCHU KARABASKIEGO}

Nie jest dokładnie jasne, kiedy Górski Karabach został zasiedlony przez Ormian ${ }^{18}$. Historycy tego regionu wskazują, że Ormianie mogli pojawić się tam z początkiem ery chrześcijańskiej ${ }^{19}$, a nawet wcześniej, czego dowodem są odkryte przez archeologów pozostałości ormiańskiego miasta Tigranakertu, założonego między 99 a 55 r. p.n.e. za czasów panowania króla Tigrana Wielkiego. W następnych stuleciach obszary te były zamieszkiwane przez różne narody, a Karabach przechodził pod władanie kolejnych imperiów. W wiekach średnich znaczna część ludności przyjęła chrześcijaństwo. Do dziś świadectwem tego pozostają średniowieczne zabytki chrześcijańskiej architektury, jak klasztory Dadiwank, Gandzasar i Gyticzawank. W swoich dziejach Górski Karabach najeżdżany był przez Turków seldżuckich, Arabów i Persów.

Na początku XIX w., w wyniku zwycięskiej wojny z Persją, Górski Karabach stał się częścią Imperium Rosyjskiego. Po pewnym czasie wszedł w skład jednostki administracyjnej zwanej Gubernią Jelizawietpolską i pozostał w niej do czasów wybuchu rewolucji październikowej. Jak napisał Zbigniew Rokita, w XIX w. historia Górskiego Karabachu i Rosji zbiegają się ze sobą ${ }^{20}$.

Przez niedługi czas, bo od 22 kwietnia 1918 do 26 maja 1918 r. Ormianie, Gruzini i Azerowie tworzyli Zakaukaską Demokratyczną Republikę Federacyjną, a Górski Karabach stał się jej integralną częścią. Federacja Zakaukaska wyłoniła się z ruin imperium carskiego, powstała w obliczu bezpośredniego zagrożenia inwazją armii osmańskiej i ambicji imperialnych władz radzieckich. Państwo to było sztucznym tworem, funkcjonowało krótko i szybko rozpadło

\footnotetext{
${ }^{18} \mathrm{~W}$ debacie o prawach do Górskiego Karabachu podnosi się głównie dwa argumenty: 1) historyczny, to jest długość zamieszkiwania tych ziem przez ludność ormiańską oraz 2) polityczny (arbitralny) dotyczący podziału i oddzielenia części ziem etnicznie ormiańskich przez zewnętrzne mocarstwa (np. tworzenie nowych republik narodowych przez ZSRR) i przekazywanie ich Azerbejdżanowi.

${ }^{19}$ G. Galojan, K. Сhudawerdjan, Нагорный Карабах. Историческая справка (Ереван: Академия Наук Армянской ССР, 1988), 10; Z. RoкITA, „Historia konfliktu górskokarabaskiego i jego miejsce w polityce zagranicznej Federacji Rosyjskiej”, Pisma Humanistyczne 7 (2010): 135.

${ }^{20}$ ROKITA, „Historia konfliktu”, 135-136.
} 
się na trzy organizmy polityczne: Armenię, Gruzję i Azerbejdżan ${ }^{21}$. Obszary Górskiego Karabachu, a także Zangezuru i Nachiczewania stały się kością niezgody między Azerami a Ormianami ${ }^{22}$.

Działania wojenne między Azerami i Ormianami rozpoczęły się już w 1919 r. Pod ich wpływem Wielka Brytania, występując w imieniu aliantów, przyznała sporne tereny Azerom. Wynikało to z nadziei na uzyskanie dostępu do złóż ropy naftowej w basenie Morza Kaspijskiego. W następnym roku w Górskim Karabachu doszło do zbrojnego powstania Ormian. W odpowiedzi na ten krok Azerowie rozpoczęli thumienie rozruchów ormiańskich. W tym samym czasie Armia Czerwona zajęła Baku i powołała zależną od Moskwy Azerbejdżańską Socjalistyczną Republikę Radziecką. Kilka miesięcy później uczyniła to samo z Armenią, to znaczy w listopadzie 1920 r. wkroczyła do Erywania, proklamując Armeńską Socjalistyczną Republikę Radziecką ${ }^{23}$.

W 1920 r. Zakaukazie zostało zajęte przez bolszewików. Dnia 4 lipca 1921 r. kaukaskie biuro Radzieckiej Partii Komunistycznej zwołało sesję plenarną w Tbilisi, potwierdzając przynależność Górskiego Karabachu do Armeńskiej Socjalistycznej Republiki Radzieckiej. Jednak po natychmiastowej interwencji Józefa Stalina decyzja ta została zrewidowana i w nocy 5 lipca zadecydowano o jego włączeniu do radzieckiego Azerbejdżanu, nie bacząc na fakt, iż ponad $86,6 \%$ mieszkańców stanowili Ormianie ${ }^{24}$. W zamian za to Azerbejdżańska Socjalistyczna Republika Radziecka miała zapewnić autonomię regionalną Górskiemu Karabachowi. Dopiero po dwóch latach ustanowiono autonomię ormiańskiej części Górnego Karabachu. Jednak w państwie sowieckim decyzja ta miała charakter czysto deklaratywny. W wyniku działań politycznych malała liczba Ormian i szkół ormiańskich, a język ormiański został praktycznie wykluczony ze sfery oficjalnej. Nie dochodziło jednak do otwartych walk ormiańsko-azerskich. W czasach sowieckich w skutek utraty niepodległości przez Azerbejdżan i Armenię konflikt narodowy o Górski Karabach został „zamrożony”25. Jednakże nie oznaczało to całkowitego zaniechania przez Ormian artykułowania swoich problemów w Górskim Karabachu.

${ }^{21}$ A. Brisku, T. BLAuvelt, „Who wanted the TDFR? The making and the breaking of the Transcaucasian Democratic Federative Republic. Caucasus Survey”, Academia.edu, https:// www.academia.edu/41714565/Who_wanted_the_TDFR_The_making_and_the_breaking_of_the_ Transcaucasian_Democratic_Federative_Republic (dostęp: 1.03.2020).

${ }^{22}$ ROKITA, „Historia konfliktu”, 136.

${ }^{23}$ IBIDEM

${ }^{24}$ H. SARGSYAN, „Население Нагорного Карабаха за 100 лет (1823-1923 гг.) (Этнодемографическое исследование)", Проблемы арменоведения $\mathrm{nr} 76$ (2) (2016): 77.

${ }^{25}$ RoKITA, „Historia konfliktu”, 137. 
W latach 60., w trakcie odwilży politycznej w Związku Radzieckim, Ormianie z inicjatywy działaczy Autonomicznego Regionu Górskiego Karabachu (NKAO - Наго́рно-Караба́хская автоно́мная о́бласть) skierowali list do ówczesnego przywódcy Nikity Chruszczowa z prośbą o rozważenie kwestii przyłączenia Górskiego Karabachu i wszystkich sąsiednich regionów do Armeńskiej Socjalistycznej Republiki Radzieckieje ${ }^{26}$. Nie spotkało się to jednak z akceptacją najwyższego kierownictwa partii komunistycznej i władz ZSRR. Sprawa Górskiego Karabachu powróciła w 1977 r., kiedy rozpoczęła się ogólnokrajowa dyskusja na temat nowej konstytucji ZSRR. W listach do Komitetu Centralnego partii komunistycznej członkowie kierownictwa NKAO apelowali o przyłączenie Górskiego Karabachu do socjalistycznej Armenii ${ }^{27}$. Problem nagłaśniany przez Ormian był skutecznie odsuwany przez sekretarzy partyjnych i centralne władze związkowe, którzy nie podejmowali żadnych decyzji dotyczących zmian statusu tego regionu.

Szansa dla Ormian pojawiła się wraz z nadejściem pierestrojki i dojściem do władzy Michaiła Gorbaczowa. W 1986 r. działacze związani z NKAO wystosowali listy do Komitetu Centralnego KPZR, żądając dostępu do ormiańskich programów telewizyjnych dla ludności Górskiego Karabachu i wprowadzenia do szkół obowiązkowego nauczania historii Armenii oraz języka ormiańskiego. Wszystkie te postulaty były wysuwane w ramach pierestrojki i liberalizacji życia publicznego w ZSRR. W 1987 r. rozpoczęto zbieranie podpisów w sprawie włączenia Karabachu do Armeńskiej Socjalistycznej Republiki Radzieckiej. Złożono ponad 200 tysięcy podpisów, które zebrano wśród ludności Górskiego Karabachu i innych ormiańskich regionów Związku Radzieckiego ${ }^{28}$. Pod koniec 1987 r. protesty i masowe spotkania były coraz liczniejsze i stawały się zalążkami dobrze zorganizowanego ruchu ormiańskiego ${ }^{29}$. Wcześniejsze żądania na rzecz ochrony środowiska naturalnego przenikały się z żądaniami przyłączenia Górskiego Karabachu do Armeńskiej SRR.

Relacje pomiędzy Ormianami a Azerami zaczęły być coraz trudniejsze. W październiku 1987 r. mieszkańcy wioski Czardachły w Górskim Karabachu, etnicznie zdominowanej przez Ormian, nie zgodzili się, aby lokalnej społeczności przewodniczył Azer. Sekretarz rejonowego komitetu partii realizujący politykę władz Azerbejdżańskiej SRR próbował usunąć z funkcji dyrektora

\footnotetext{
${ }^{26}$ L. AleKSEJeWA, История инакомыслия в СССР: новейший период (Москва: Московская Хельсинкская группа, 2012), 79.

${ }^{27}$ IBIDEM, 79-81.

${ }^{28}$ B. Ulubabyan, Arcachjan gojapajkari taregrutjun (Erywań, 1997), 10-18.

${ }^{29}$ A. YAMSKOv, „Ethnic Conflict in the Transcausasus: The Case of Nagorno-Karabakh”, Theory and Society $20 \mathrm{nr} 5$ (1991): 633-634.
} 
kołchozu Ormianina i obsadzić stanowisko swoim protegowanym. Konflikt w kołchozie wywołał bunt Ormian, co doprowadziło do represji milicji azerskiej i członków partii komunistycznej. Wkrótce działania prewencyjne władz w Baku spowodowały całkowite usunięcie ludności ormiańskiej z tej wsi.

Po tych wydarzeniach w różnych miejscach w Armenii wybuchły demonstracje solidaryzujące się z mieszkańcami Czardachły i potępiające działania azerskie. Protesty Ormian przybrały na sile w lutym 1988 r. Dnia 13 lutego w Stepanakercie i innych regionach zamieszkałych przez Ormian protestujący zażądali wyjścia Górskiego Karabachu z Azerbejdżańskiej SRR i przyłączenia do Armeńskiej SRR. Na fali tych wystąpień Regionalna Rada Deputowanych Ludowych Górskiego Karabachu 20 lutego 1988 r. podjęła uchwałę o secesji i połączeniu regionu z Armeńską SRR. Tego samego dnia doszło do wielkich protestów ludności w Erywaniu wspierających te dążenia. W celu ich koordynowania stworzony został Armeński Komitet Ruchu Karabach (Karabaghian szarżman Hajastani komite), a przewodniczył mu Igor Muradian. Demonstracje przyciągnęły prawie wszystkie warstwy społeczeństwa armeńskiego, włączając nawet hierarchów Kościoła ormiańskiego, którzy otwarcie popierali hasła głoszone na ulicach Erywania. Ten dzień stał się symboliczną datą powstania ruchu karabaskiego ${ }^{30}$.

Dnia 22 lutego 1988 r. pierwszy sekretarz partii komunistycznej Karen Demirczian w przemówieniu do narodu w telewizji publicznej stwierdził, że podjęte decyzje w sprawie Górskiego Karabachu są sprzeczne z wolą robotników Armeńskiej i Azerbejdżańskiej SRR. Dzień później ruch karabaski został potępiony także przez Centralny Komitet Partii Komunistycznej ZSRR, który stwierdził, że jego potrzeby są sprzeczne z interesami narodów azerskiego i ormiańskiego, a także szkodzą stosunkom etnicznym w regionie oraz mają wymiar ekstremistyczny i nacjonalistyczny. Tym samym władze centralne nie uznały secesji Górskiego Karabachu ${ }^{31}$. Zwolennicy ruchu wzmogli swoje działania, a ulicznym wystąpieniom towarzyszyły strajki w zakładach pracy i głodówki. Ruch karabaski wyrósł na ważnego politycznego aktora, do czego władze sowieckiej Rosji nie chciały się przyznać. Nasilająca się krytyka

\footnotetext{
${ }^{30}$ H. MARUTYAN, „The Karabakh Movement or What was Happening in Soviet Armenia 30 Years Ago", EVN Report, 25.02.2018, https://www.evnreport.com/politics/the-karabakh-movement-orwhat-was-happening-in-soviet-armenia-30-years-ago (dostęp: 5.03.2020).

${ }^{31}$ Fragmenty przemówienia pierwszego sekretarza partii komunistycznej ZSRR Karena Demircziana i stanowiska Centralnego Komitetu Partii Komunistycznej ZSRR znaleźć można na stronach: https:/www.evnreport.com/politics/karabakh-movement-88-a-chronology-of-events-on-the-roadto-independence (dostęp: 05.03.2020).
} 
ze strony władz ZSRR sprawiała, że ruch karabaski stawał się powoli ruchem antyradzieckim.

Podczas gdy w Erywaniu trwały masowe wiece, 26 lutego 1988 r. poetka Silwa Kaputikian oraz dziennikarz i pisarz Zori Balajan, członkowie komitetu ruchu karabaskiego, spotkali się w Moskwie z Michaiłem Gorbaczowem, przedstawiając mu osobiście postulaty ruchu i obawy dotyczące ludności ormiańskiej w Górskim Karabachu. Po spotkaniu Gorbaczow obiecał, że problem Karabachu zostanie szeroko przedyskutowany i wezwał do zachowania spokoju. Tego samego dnia przywódcy ruchu karabaskiego zaczęli nawoływać do miesięcznego zawieszenia wszystkich demonstracji ${ }^{32}$. Jednakże nieoczekiwanym zwrotem w kierunku dalszej radykalizacji nastrojów politycznych stały się wydarzenia w Sumgaicie.

\section{POGROM ORMIAN W SUMGAICIE}

To, co działo się za sprawą ruchu karabaskiego, nie pozostawało obojętne dla całego społeczeństwa azerbejdżańskiego, wśród którego zaczęły wzbierać nastroje antyormiańskie. W dniach od 27 do 29 lutego 1988 r. w Sumgaicie, mieście oddalonym zaledwie 35 kilometrów na północ od stolicy Azerbejdżanu Baku, doszło do pogromu ludności ormiańskiej. W tym okresie w Sumgaicie mieszkało ponad 200 tysięcy osób, w tym ponad 18 tysięcy Ormian. Przez trzy dni grupy złożone z Azerów atakowały i zabijały Ormian w ich domach i na ulicach. Ormiańska mniejszość etniczna poddana została zorganizowanej masakrze i masowej przemocy. Tragedia ta dokonała się za przyzwoleniem Azerbejdżańskiego Frontu Ludowego oraz władz lokalnych ${ }^{33}$.

Trwający trzy dni pogrom Ormian w Sumgaicie wyzwolił do tej pory uśpioną „kulturę przemocy” "34. Przerażający opis tych wydarzeń zanotował brytyjski pisarz i dziennikarz Thomas de Waal: „Pogrom Ormian zaczął się 28 lutego 1988 r. Zezwierzęcony tłum Azerbejdżan - mężczyzn w wieku od 13 do 50 lat otaczał dom za domem w 3. osiedlu i grupami po 20-30 osób z okrzykami »Śmierć Ormianom!« wdzierał się do uprzednio wyznaczonych mieszkań rodzin ormiańskich. Grupy bandytów były uzbrojone w siekiery,

${ }^{32}$ Ulubabyan, Arcachjan gojapajkari taregrutjun, 25-30.

${ }^{33}$ S. Shahmuratian, The Sumgait Tragedy. Pogroms against Armenians in Soviet Azerbaijan, vol. I: Eyewitness Accounts, trans. J. Steven (New Rochelle, N.Y., Cambridge, Mass.: Zoryan Institute for Contemporary Armenian Research and Documentation, 1990).

${ }^{34}$ L. ABRAhAmian, „Typology of Aggressiveness and National Violence in the Former USSR”, International Journal on Minority and Group Rights 4 (1997): 263. 
łomy, noże, kije, brukowce, które również zawczasu zostały na wywrotkach zawiezione pod domy, w których zaczynał się pogrom. Wszystko było zaplanowane. Bandyci najpierw bestialsko mordowali wszystkich przebywających w mieszkaniu członków rodzin, nie szczędząc ani starców, ani kobiet, ani dzieci, po czym w barbarzyński sposób niszczyli całe mienie, które znajdowało się w mieszkaniu i przez okna wyrzucali na podwórze, gdzie tłum oblewał rzeczy benzyną i podpalał. Ormian niedobitych w mieszkaniach bandyci wywlekali na ulice i zezwierzęcony tłum za pomocą siekier i łomów dobijał nieszczęsnych ludzi”35.

Według oficjalnych danych zginęło 29 Ormian i trzy osoby innej narodowości, nie ustalono liczby rannych. Strona ormiańska uważa, że w Sumgaicie zginęło znacznie więcej osób i przynajmniej kilkaset zostało poszkodowanych. Wszystko odbywało się przy biernej postawie radzieckich służb bezpieczeństwa. Ofiar mogło być więcej, gdyby nie postawa setek Azerbejdżan, którzy ryzykując swoim życiem chronili i ratowali swoich ormiańskich sąsiadów $^{36}$. Ormianie $w$ tych masakrach zaczęli dopatrywać się podobieństw do ludobójstwa swojego narodu z 1915 r. Domagali się politycznej oceny tych wydarzeń ze strony władz Związku Radzieckiego. Takiej oceny jednak nie było. Zamiast tego w mediach sowieckich napiętnowano jedynie strajki w Stepanakercie i Erywaniu, a ruch karabaski określano mianem antysocjalistycznego i zagrażającego nienaruszalności terytorialnej radzieckiego Azerbejdżanu ${ }^{37}$.

Bierność wobec pogromów ludności ormiańskiej oraz krytyka przez władze w Moskwie sprawiły, że ruch karabaski przyjął postawę antyradziecką. O ile na samym początku występował pod hasłami pierestrojki, tak od tego momentu stał się ruchem antysystemowym i antysowieckim.

Pogrom Ormian w Sumgaicie był katalizatorem dla ożywienia kolejnych protestów ormiańskich. Na początku marca 1988 r. Komitet Karabach pozwolił na tworzenie lokalnych komitetów zakładanych niemal we wszystkich przedsiębiorstwach. W tym samym czasie w Górskim Karabachu utworzony został Komitet Krunk (arm. Żuraw), który pełnił analogiczną funkcję co Komitet Karabach. Komitet Krunk koordynował działania w Górskim Karabachu, zaś Komitet Karabach postanowił działać przede wszystkim w Erywaniu.

${ }^{35}$ T. WAAL de, Black Garden. Armenia and Azerbaijan through Peace and War (New YorkLondon: New York University Press, 2003), 23. Niniejszy cytat w thumaczeniu polskim podaję za: Z.T. SzMURŁo, „Pierestrojka i tragiczne wydarzenia w Sumgaicie”, Studia Gdańskie. Wizje i rzeczywistość 10 (2013): 278.

${ }^{36}$ SZMurŁo, „Pierestrojka i tragiczne wydarzenia w Sumgaicie”, 278.

${ }^{37}$ IBIDEM, 279. 
Wrzenie społeczne zarówno w Stepanakercie, jak i w Erywaniu było coraz większe. Ruch karabaski zaplanował na 26 marca wielką manifestację na placu przed Operą w Erywaniu zaraz po decyzjach, które zapadły w trakcie sesji plenarnej Komitetu Okręgowego Górskiego Karabachu. Komitet ten zadecydował o przyłączeniu regionu do Armeńskiej SRR. W odpowiedzi rząd w Moskwie 22 marca 1988 r. wysłał wojsko, aby zablokować zaplanowany wiec. W mieście ogłoszono godziny policyjne, demonstracje zostały zakazane, a Komitet Karabach uznano za nielegalny. Erywań stał się miastem oblężonym przez armię radziecką.

\section{W DRODZE DO NIEPODLEGŁOŚCI}

Kiedy ruch karabaski stał się ruchem antyradzieckim, nastąpiła zmiana członków w Komitecie Karabachu. Dotychczasowi działacze Igor Muradian, Zori Balajan, Silwa Kaputikian wierzyli, że problemy Górskiego Karabachu można rozwiązać w ramach Związku Radzieckiego i pierestrojki. Rzeczywistość zrewidowała ich ideały. Czując, że ruch karabaski zaczyna stanowić poważne zagrożenie dla systemu sowieckiego, wycofali się z działalności w Komitecie. Komitetowi zaczęła przewodniczyć grupka intelektualistów, na czele z Wazgenem Manukianem oraz Lewonem Ter-Petrosjanem ${ }^{38}$. Od tego momentu kwestia niepodległości Armenii i zmiany systemu sowieckiego były formułowane $\mathrm{z}$ całą stanowczością.

Pomimo braku przyzwolenia rządu w Moskwie w Erywaniu trwały kilkutysięczne manifestacje. Do tego dochodziły strajki w zakładach pracy i demonstracje w innych ormiańskich miastach. Dnia 28 maja 1988 r. w 70. rocznicę Pierwszej Republiki Armenii (1918-1920) demonstranci oprócz transparentów popierających przyłączenie Górskiego Karabachu i krytykujących partię komunistyczną trzymali w rękach trójkolorową flagę Armenii. Kwestia suwerenności państwowej stawała się priorytetowa. Dzięki ruchowi karabaskiemu udało się zjednoczyć Ormian zarówno w walce o niepodległość, jak i wzbudzić w nich silne poczucie tożsamości narodowej ${ }^{39}$.

W następnych dniach aktywiści wysunęli żądania zwołania obrad parlamentu armeńskiego. Zawiązano nawet specjalne grupy zwane Grupami Konstytucyjnymi,

\footnotetext{
${ }^{38}$ R. Panossian, „Post-Soviet Armenia”, w After Independence. Making and Protecting the Nation in Postcolonial and Postcommunist States, ed. L.W. Barrington (Michigan: University of Michigan Press, 2006), 228.

${ }^{39}$ IBIDEM, 229-230.
} 
które współpracowały z posłami i omawiały kierunki przyszłych zmian. Ostatecznie parlament armeński zebrał się na wniosek samych posłów. Sytuacja ta powtórzyła się jeszcze w listopadzie tego samego roku. Co ważne, te ostatnie obrady miały miejsce w budynku Opery, przed którą zazwyczaj zbierali się demonstranci. Aby zapewnić kworum, niektórzy posłowie byli eskortowani do Opery przez przedstawicieli ruchu karabaskiego. W trakcie sesji posłowie m.in. sprzeciwili się projektowi wyborów narzuconemu przez rząd w Moskwie, nie zgodzili się też na ratyfikowanie poprawek do konstytucji ZSRR, uznając je za antydemokratyczne. Wśród innych decyzji podjętych w czasie zjazdu były te głoszące, że pogromy w azerskim Sumgaicie były przejawem ludobójstwa Ormian oraz że na terytorium Armenii będą obowiązywały wyłącznie ustawy zatwierdzone przez miejscowy parlament ${ }^{40}$. Pod koniec 1988 r. ruch karabaski był już ważną siłą polityczną, posiadającą duże poparcie społeczne w Armeńskiej SRR. Przez władze ZSRR był postrzegany jak zagrożenie dla istniejącego ładu politycznego. Dlatego na rozkaz rządu w Moskwie podjęto różnorodne działania w celu jego osłabienia. Wobec ludzi związanych $\mathrm{z}$ ruchem karabaskim formułowano zarzuty naruszania porządku publicznego czy podżegania do nienawiści etnicznej. W grudniu 1988 r. członkowie Komitetu Karabachu zostali aresztowani, wśród nich między innymi Lewon Ter-Petrosjan. $\mathrm{Z}$ więzienia w Moskwie zostali uwolnieni dopiero w połowie maja $1989 \mathrm{r}^{41}$

Represje, które spadły na wielu członków ruchu karabaskiego, utwierdziły jeszcze bardziej w swoich przekonaniach zarówno jego przywódców, jak i ludzi protestujących na ulicach, że jedynym skutecznym sposobem wprowadzenia zmian jest dążenie do niepodległości Armenii. Dnia 7 listopada 1989 r. władze sowieckie zorganizowały w Erywaniu paradę z okazji rocznicy rewolucji październikowej, która z dezaprobatą została przyjęta przez społeczeństwo ormiańskie. Kilka dni później, 18 listopada ruch karabaski zorganizował własną manifestację, w której uczestniczyło kilkaset tysięcy ludzi ${ }^{42}$. Dysonans pomiędzy tymi dwoma wydarzeniami pokazał rzeczywiste oczekiwania społeczeństwa ormiańskiego. Odrzucenie gorbaczowowskiej „rewolucji z góry” na rzecz rewolucji oddolnej stało się faktem.

Zwieńczeniem działań ruchu karabaskiego były wybory do Rady Najwyższej Armeńskiej SRR przeprowadzone 20 maja i 3 czerwca 1990 r., które

\footnotetext{
${ }^{40}$ Marutyan, ,The Karabakh Movement”.

${ }^{41}$ P. Nieczuja-OstrowsKi, „Wystąpienia społeczne w Republice Armenii w latach 1991-2012”, Nowa Polityka Wschodnia nr 2 (3) (2012): 110.

${ }^{42}$ MARUTYAN, „The Karabakh Movement”.
} 
zakończyły się klęską rządzącej przez lata Komunistycznej Partii Armenii. Po kilku rundach głosowania członek Komitetu Karabach i ruchu karabaskiego Lewon Ter-Petrosjan został wybrany przewodniczącym Rady Najwyższej, a we wrześniu inny aktywista tego samego ruchu i Komitetu Wazgen Manukian objął stanowisko premiera ${ }^{43}$. Natomiast 23 sierpnia 1990 r. przyjęta została Deklaracja niepodległości, która oznaczała początek przejścia od kraju sowieckiego do budowy niezależnej republiki demokratycznej. Ostatecznie 21 września 1991 r. Armenia została niepodległym krajem. Za sprawą masowego zrywu ludności i ruchu karabaskiego dokonał się transfer władzy, która z rąk komunistów przejęta została przez prodemokratyczną i dążącą do suwerenności opozycję.

\section{PODSUMOWANIE}

Ruch karabaski był jednym z pierwszych ruchów społecznych, które wstrząsnęły komunizmem w Europie Wschodniej i pierwszym na obszarze byłych republik radzieckich. W krótkim czasie przyjął on zorganizowane formy protestu, przyczyniając się do upadku ZSRR i zmian w konfiguracji politycznej państw ówczesnego bloku sowieckiego. Jednocześnie obnażył nieskuteczność władzy radzieckiej i polityki pieriestrojki Michaiła Gorbaczowa. Bez wątpienia ruch ten odegrał istotną rolę w demokratyzacji społeczeństw regionu i w eliminacji totalitarnego systemu komunistycznego. Mimo swojej doniosłości pozostaje wciąż „nierozpoznaną rewolucją"44. Jak wskazuje Ashot Sargsyan, szczególnie po rezygnacji ze stanowiska prezydenta Lewona Ter-Petrosjana w 1998 r., historia ruchu zaczęła być zniekształcana i wypaczana ${ }^{45}$, często redukowana wyłącznie do płaszczyzny konfliktu etnicznego pomiędzy Azerbejdżanem a Armenią ${ }^{46}$.

Analiza działań ruchu karabaskiego pokazuje, że w rzeczywistości ulegał on głębokiej ewolucji. Jego korzenie tkwią w oddolnych ruchach ekologicznych połowy lat 80 . XX w., które w tym czasie stały się aktywne w Armeńskiej Socjalistycznej Republice Radzieckiej. Ormiański ekologizm szybko

${ }^{43}$ NieCZUjA-OSTROWSKI, „Wystąpienia społeczne”, 111.

${ }^{44}$ MARUTYAN, „The Karabakh Movement”.

${ }^{45}$ A. SARGSYAN, Kharabachjan szarzman patmutjun 1988-1989 (Erywań: Antares, 2018), 56.

46 J. SHERR, „Nagorno-Karabakh Between Old and New Geopolitics”, w The International Politics of the Armenian-Azerbaijani Conflict. The Original "Frozen Conflict" and European Security, ed. S.E. Cornell (New York: Palgrave Macmillan, 2017), 49-69. 
rozszerzał swój program polityczny o kwestie etniczne, przekształcając się tym samym w ruch narodowościowy. Następnie formy artykułowania dążeń społecznych wokół kwestii Górskiego Karabachu i odłączenia go od sowieckiego Azerbejdżanu poszerzone zostały o żądania zmiany istniejącego systemu politycznego, a wreszcie do suwerenności państwowej.

Kiedy ruch karabaski stanowił już poważną siłę polityczną, jego głównym celem stała się niepodległość Armenii. Należy jednak wziąć pod uwagę, iż zadanie to osiągnięte zostało w ,zniekształconej” formie. Ruch karabaski nie zdołał bowiem zrealizować jednego ze swoich priorytetowych żądań, a mianowicie zjednoczenia Górskiego Karabachu z Armenią. Dziś Górski Karabach wciąż pozostaje spornym terytorium między Armenią a Azerbejdżanem, jest quasi-państwem nieuznawanym na arenie międzynarodowej.

Najbardziej dystynktywną cechą tego ruchu był jego ogólnonarodowy charakter. Różne formy protestu, jak demonstracje, okupowanie budynków, strajki czy głodówki były udziałem wielu tysięcy Ormian. Co więcej, były one organizowane niemal nieprzerwanie od 1988 do 1990 r. Ruch karabaski opierał się na zasadach solidaryzmu narodowego, odwoływał się do wspólnotowości i obywatelskiej jedności Ormian. Nakładały się na nie kwestie antysystemowości, krytyki sowieckiej polityki i konfliktu etnicznego, co nadało ruchowi karabaskiemu szczególną postać

Oddolne polityczne działania członków i sympatyków ruchu, będące udziałem dużych grup społecznych, były od samego początku walką pokojową. Jako ruch reformatorski pokładał nadzieje w gorbaczowowskiej odwilży politycznej w ZSRR i pieriestrojce. Kiedy radziecka „zmiana z góry” poniosła fiasko, ruch wykorzystał drogę konstytucyjną, inicjując Grupy Konstytucyjne wpływające na posłów parlamentu armeńskiego i ostatecznie - wygrywając w demokratyczny sposób wybory - przyczynił się do niepodległości Armenii. Jego pokojowy charakter przejawiał się także w formach protestu, które w „szarej” rzeczywistości sowieckiej nabierały cech społecznego „karnawału". Choćby towarzyszące masowym zgromadzeniom plakaty czy hasła były nie tylko wskaźnikami nastrojów politycznych, lecz także wyrażały obawy i życzenia ludzi tamtej epoki ${ }^{47}$. Centralną sceną tych „widowisk” był rozległy plac wokół Opery w Erywaniu, czyli obecny Plac Niepodległości.

Oczywiście ruchowi karabaskiemu towarzyszyło silne poczucie przynależności do wspólnoty narodowej. Niemniej ruch ten nie był „czystym” ruchem

${ }^{47}$ H. Marutyan, „The Slogans, Posters and Language of the Karabakh Movement”, EVN Report, 15.04.2018, https://www.evnreport.com/politics/the-slogans-posters-and-language-of-thekarabakh-movement (dostęp: 5.03.2020). 
narodowościowym. W obrębie działań zbiorowych artykułowano inne problemy: zanieczyszczenia powietrza (,ruch ekologiczny”), demokratyzacji życia społecznego (,ruch na rzecz praw obywatelskich”), zmiany systemu („ruch antykomunistyczny”), przyłączenia Górskiego Karabachu („ruch etnicznego wyzwolenia") czy sprzeciwu wobec władzy osiąganego metodami pokojowymi (,ruch pacyfistyczny”). Jego konsolidacja opierała się więc na wielu elementach. Ruch karabaski wypalił się wraz z osiągnięciem przez Armenię niepodległości, co wiązało się także z wytworzeniem przez niego odpowiedniej struktury organizacyjnej, która jego liderom zapewniła sukces w pierwszych wolnych wyborach parlamentarnych i prezydenckich.

\section{BIBLIOGRAFIA}

ABrahamyan, Lewon. „Chaos and Cosmos in the Structure of Mass Popular Demonstrations (The Karabakh Movement in the Eyes of an Ethnographer)". Anthropology \& Archeology of Eurasia 29, nr 2 (1990): 70-86.

ABrahamian, Lewon. „Typology of Aggressiveness and National Violence in the Former USSR”. International Journal on Minority and Group Rights 4 (1997): 263-278.

ALEKSEJEwA, Liudmila. Istoriâ inakomysliâ v SSSR: novejšij period, Moskwa: Moskowskaja Helsinskaja gruppa, 2012 [ALEKSEJEWA, Liudmila. История инакомыслия в СССР: новейший период. Москва: Московская Хельсинкская группа, 2012].

BRISKU, Adrian i Blauvelt Timothy. „Who wanted the TDFR? The making and the breaking of the Transcaucasian Democratic Federative Republic. Caucasus Survey". Academia.edu. https:// www.academia.edu/41714565/Who_wanted_the_TDFR_The_making_and_the_breaking_of_ the Transcaucasian_Democratic_Federative_Republic (dostęp: 1.03.2020).

EDELMAN, Natan. ,'Revolûciâ sverhu' V ROSSII”. NAUKA I ŽIZN' 1-3 (1989). http://vivovoco.astronet.ru/ VV/PAPERS/NYE/REV/REV 1.HTM (dostęp: 28.02.2020) [EDELMAN, Natan. „Революция сверху' в России”. НАУКА И ЖИЗНЬ 1-3 (1989). http://vivovoco.astronet.ru/VV/PAPERS/NYE/ REV/REV_1.HTM (dostęp: 28.02.2020)].

FITZPATRIC, Sheila. Everyday Stalinism. Ordinary life in extraordinary times: Soviet Russia in the 1930s. New York-Oxford: Oxford University Press, 1999.

GeukJian, Ohannes. „The Politicization of the Environmental Issue in Armenia and Nagorno-Karabakh's Nationalist Movement in the South Caucasus 1985-1991”. Nationalities Papers 35, nr 2 (2007): 233-265.

GAlOJAn, Galust i CHUdAWERDJAn Konstantin Nagornyj Karabah. Istoričeskaâ spravka. Erywań: Izdatel'tvo Akademii Nauk Armânskoj SSR, 1988 [GALOJAN, Galust i CHUDAWERDJAN Konstantin Нагорный Карабах. Историческая справка. Ереван: Академия Наук Армянской ССР, 1988].

LyytikÄInen, Laura. Performing Political Opposition in Russia. The Case of the Youth Movement Oborona. Helsinki: University of Helsinki, 2014.

MARUTYAN, Harutyun. „Iconography of Historical Memory and Armenian National Identity at the End of the 1980s". W Representations on the Margins of Europe. Politics and Identities in the 
Baltic and South Caucasian States, ed. T. Darieva, W. Kaschuba, 89-113. Frankfurt-Chicago: Chicago University Press, 2007.

MARUTYAN, Harutyun. „The Karabakh Movement or What was Happening in Soviet Armenia 30 Years Ago". EVN Report, 25.02.2018. https://www.evnreport.com/politics/the-karabakh-movement-orwhat-was-happening-in-soviet-armenia-30-years-ago (dostęp: 5.03.2020).

MARUTYAN, Harutyun. „The Slogans, Posters and Language of the Karabakh Movement”. EVN Report, 15.04.2018. https://www.evnreport.com/politics/the-slogans-posters-and-language-of-thekarabakh-movement (dostęp: 5.03.2020).

NIECZUJA-OSTROWSKI, Paweł. „Państwo i społeczeństwo wobec wyzwań i przemian współczesności”. W Armenia. Dziedzictwo a współczesne kierunki przemian kulturowo-cywilizacyjnych, red. P. Nieczuja-Ostrowski, 60-96. Poznań: Fundacja na rzecz Czystej Energii, 2016.

NiecZuja-Ostrowski, Paweł. „Wystąpienia społeczne w Republice Armenii w latach 19912012”. Nowa Polityka Wschodnia nr 2 (3) (2012): 109-128.

OlsZewski, Paweł. „Konflikt azerbejdżańsko-ormiański o Górski Karabach”. W Sąsiedztwo i pogranicze - między konfliktem a wspótpraca, t. I, red. R. Łoś, J. Regina-Zacharski, 175-201. Łódź: Wydawnictwo Uniwersytetu Łódzkiego, 2012.

OSWALD, Ingrid i VORONKOV Viktor. „The 'public-private' sphere in Soviet and post-Soviet society. Perception and dynamic of 'public' and 'private' in contemporary Russia". European Societies 6, nr 1 (2004): 97-117.

Panossian, Razmik. „Post-Soviet Armenia”. W After Independence. Making and Protecting the Nation in Postcolonial and Postcommunist States, ed. L.W. Barrington, 225-247. Michigan: University of Michigan Press, 2006.

PAPAZYAN, Sabrina. „The Cost of Memorializing. Analyzing Armenian Genocide Memorials and Commemorations in the Republic of Armenia and in the Diaspora". International Journal for History, Culture and Modernity 7 (2019): 55-86.

PIsOwicz, Andrzej. „O polskiej transkrypcji wyrazów ormiańskich”. Przegląd Orientalistyczny 2 (1979): 158-162.

PorTA, Donatella della i DiAni Mario. Ruchy społeczne. Wprowadzenie, przeł. A. Sadza. Kraków: Wydawnictwo Uniwersytetu Jagiellońskiego, 2009.

RoKITA, Zbigniew. „Historia konfliktu górskokarabaskiego i jego miejsce w polityce zagranicznej Federacji Rosyjskiej”. Pisma Humanistyczne 7 (2010): 135-147.

SARGSYAN, Ashot. „Kharabachjan szarzman patmutjun 1988-1989 [Historia ruchu karabaskiego 1988-1989]”. Erywań: Antares, 2018.

SARGSYAN, Hamlet. „Naselenie Nagornogo Karabaha za 100 let (1823-1923 gg.) (Ètnodemografičeskoe issledovanie)”. Problemy armenologii nr 76 (2) (2016) [Sargsyan, Hamlet. „Население Нагорного Карабаха за 100 лет (1823-1923 гг.) (Этнодемографическое исследование)”. Проблемы арменоведения $\mathrm{nr} 76$ (2) (2016): 59-81].

Shahmuratian, Samvel. The Sumgait Tragedy. Pogroms against Armenians in Soviet Azerbaijian, vol. I: Eyewitness Accounts, trans. J. Steven. New Rochelle, N.Y., Cambridge, Mass.: Zoryan Institute for Contemporary Armenian Research and Documentation, 1990.

SHERR, James. „Nagorno-Karabakh Between Old and New Geopolitics”. W The International Politics of the Armenian-Azerbaijani Conflict. The Original "Frozen Conflict" and European Security, ed. S.E. Cornell, 49-69. New York: Palgrave Macmillan, 2017. 
SunY, Ronald Grigor. „Writing Genocide: The Fate of the Ottoman Armenians”. W A Question of Genocide. Armenians and Turks at the End of the Ottoman Empire, ed. R.G. Suny, F.M. Gocek, N.M. Naimark, 15-41. Oxford-Nowy York: Oxford University Press, 2011.

SzmuRŁo, Zbigniew T. „Pierestrojka i tragiczne wydarzenia w Sumgaicie”. Studia Gdańskie. Wizje i rzeczywistość 10 (2013): 267-284.

UlubABYAn, Bagrat. Arcachjan gojapajkari taregrutjun [Kronika oporu Artsakh]. Erywań, 1997.

WAAL, Thomas de. Black Garden. Armenia and Azerbaijan through Peace and War. New YorkLondon: New York University Press, 2003.

YAMSKov, Anatoly. „Ethnic Conflict in the Transcausasus: The Case of Nagorno-Karabakh”. Theory and Society 20, nr 5 (1991): 631-660.

ZakHarova, Larissa. „Soviet Public Sphere”. Politika, 16.05.2017. https://www.politika.io/en/notice/ soviet-public-spheres (dostęp: 28.02.2020).

Zdravomyslova, Elena i Voronkov Viktor. „The Informal Public in Soviet Society: Double Morality at Work". Social Research 69, nr 1 (2002): 49-69.

\title{
WIELKI ZRYW MAŁEGO NARODU: ZAPOMNIANY RUCH KARABASKI (1988-1990)
}

\author{
Streszczenie
}

W 1989 r. w państwach Europy Wschodniej doszło do przełomowych wydarzeń, które zmieniły historię tego regionu. „Okrągły stół” w Polsce, upadek muru berlińskiego czy „aksamitna rewolucja” w Czechosłowacji zapoczątkowały procesy liberalizacji i usamodzielnienia się od ZSRR. Z czasem transformacje te nazwano „Rewolucjami Europy Wschodniej”. Przyczyniły się one do ostatecznego upadku reżimu sowieckiego i sprawiły, że w początkach lat 90. minionego wieku obszar postradziecki uległ znaczącym przeobrażaniom społecznym, politycznym i gospodarczym.

Rok przed wspomnianymi wydarzeniami rozpoczął się wielki ruch demokratyczny w najmniejszej republice Związku Radzieckiego - Armenii, który podważył imperialną politykę władz sowieckich. Z czasem przyjął on nazwę ruchu karabaskiego. Zryw społeczeństwa armeńskiego, który wybuchł w 1988 r., wyraził potrzebę demokratyzacji społeczeństwa radzieckiego i odegrał znaczącą rolę w dążeniach wolnościowych narodu ormiańskiego. Pomimo tego niewiele wiadomo na temat tego ruchu, który powszechnie kojarzony bywa $\mathrm{z}$ antagonizmami etnicznymi między Armenią a Azerbejdżanem. Ruch karabaski pozostał ,niezauważony” w czasach sowieckich, ponieważ media reżimowe blokowały informacje o masowych wystąpieniach Ormian i konfliktach na Kaukazie. Współcześnie kwestia ruchu karabaskiego jest niewygodna z powodów politycznych, zwłaszcza gdy mówimy o stosunkach armeńsko-rosyjskich.

Zasadniczym celem artykułu jest rekonstrukcja działań ruchu karabaskiego w latach 1988-1990, a także próba zrozumienia jego wpływu na procesy, które przyczyniły się do upadku Związku Radzieckiego w kontekście przemian Europy Wschodniej.

Słowa kluczowe: ruch karabaski; ruch społeczno-polityczny; rozpad ZSRR; Armenia; procesy zmian społecznych. 


\section{THE GREAT OUTBREAK OF THE SMALL NATION: \\ THE FORGOTTEN KARABAKH MOVEMENT (1988-1990)}

\section{S u m m a r y}

In 1989, breakthrough events took place in Eastern European countries that changed the history of the region. The "round table" in Poland, the fall of the Berlin Wall or the "Velvet Revolution" in Czechoslovakia initiated the processes of liberalization and independence from the USSR. Over the time, these transformations were called "Eastern European Revolutions". They contributed to the final collapse of the Soviet regime and caused the post-Soviet area to undergo significant social, political and economic transformations in the early 1990s.

A year before these events, a great democratic movement began in the smallest Republic of the Soviet Union - Armenia, which undermined the imperial policy of the Soviet authorities. Over the time, it adopted the name of the Karabakh Movement. The rebellion of the Armenian society that broke out in 1988 expressed the need for democratization of the Soviet society and played a significant role in the freedom aspirations of the Armenian people. Despite this, little is known about this movement, which is commonly associated with ethnic antagonisms between Armenia and Azerbaijan. The Karabakh movement remained "unnoticed" in the Soviet era, because the regime media blocked information about the mass occurrences of Armenians. Today, the issue of the Karabakh Movement is uncomfortable for political reasons, especially when we talk about Armenian-Russian relations, because Russia attaches great importance to glorifying USSR history.

The main goal of the article is to reconstruct the activities of the Karabakh Movement in 1988-1990, as well as to attempt to understand its impact on the processes that contributed to the collapse of the Soviet Union in the context of transformations in Eastern Europe.

Keywords: Karabakh Movement; socio-political movement; collapse of the USSR; Armenia; process of social transformation. 